\title{
Landslide Risk Assessment for Designing Monitoring and Early Warning System
}

\author{
Tuan Anh Bui ${ }^{1}$, Teuku Faisal Fathani ${ }^{* 2,4}$, and Wahyu Wilopo ${ }^{3,4}$ \\ ${ }^{1}$ Master Program in Natural Disaster Management, Department of Civil and Environmental Engineering, Faculty of \\ Engineering, Universitas Gadjah Mada \\ ${ }^{2}$ Department of Civil and Environmental Engineering, Faculty of Engineering, Universitas Gadjah Mada, Yogyakarta \\ ${ }^{3}$ Department of Geological Engineering, Faculty of Engineering, Universitas Gadjah Mada, Yogyakarta, Indonesia \\ ${ }^{4}$ Center for Disaster Mitigation and Technological Innovation (GAMA-InaTEK)
}

\begin{abstract}
Landslide is the most frequent natural disaster in Yogyakarta, Indonesia. In the mid-March 2018, a few cracks appeared in the north of the hill in the Pendoworejo Village, Kulon Progo District, Yogyakarta Special Province. The landslide movement of this area still threatens the residents and makes them evacuated due to their fear upon potential landslide disaster. In order to reduce the risk, landslide investigation and risk assessment were conducted. The stability analysis focused on the relationship of the displacement, the velocity and the fluctuation of groundwater level due to the rainfall intensity. Then, a monitoring and warning system was designed as a non-structural mitigation effort. Based on the preliminary investigation on April 2018, there was no evidence of mass movement on the west and south part of the hill. On the other hand, the north part area was estimated to have risk as indicated by the occurrence of many cracks. Based on the result of analysis, the fluctuation of the groundwater level rose or dropped substantially before and after heavy rainfall. In the rainy season, the velocity and the displacement increased slightly in the first three months and grew rapidly afterward. In fact, the landslide risk increased in every rainy season. Therefore, the risk could be more dangerous in the future.
\end{abstract}

Keywords: Slope stability analysis · Groundwater · Rainfall intensity · Movement velocity $\cdot$ Mitigation $\cdot$ Monitoring devices.

\section{INTRODUCTION}

In the mid-March 2018, a few cracks appeared in the north of the hill in the Pendoworejo Village, Kulon Progo District, Yogyakarta Special Province. Especially, there was a serious crack across a residential house that happened in the end of March 2018. Hence, fearing the potential landslide hazard to happen due to the landslide movement in this area, the residents had to evacuate themselves.

As shown in the Figure 1, the research area included the hill of Pendoworejo Village which

\footnotetext{
${ }^{*}$ Corresponding author: T.F. FATHANI, Department of Civil and Environmental Engineering, Gadjah Mada University. Jl. Grafika 2 Yogyakarta, Indonesia. E-mail: tfathani@ugm.ac.id
}

covered approximately $1 \mathrm{~km}^{2}$. The location was situated between latitudes of $-7.755^{\circ}$ to $7.757^{\circ}$ and longitudes of $110.192^{\circ}$ to $110.189^{\circ}$. The morphology of the area consisted of terrain with steep hill and narrow valleys. The slope inclination of the research area varied from gentle to steep $\left(15^{\circ}\right.$ to $\left.58^{\circ}\right)$ with minimum and maximum of altitude that varied from $145 \mathrm{~m}$ to $270 \mathrm{~m}$ above the sea level. The study area was dominated by hilly morphology with landslide occurrence in addition to homogenous lithology composition (Karnawati, 1998). It was also in humid tropical climate condition and sensitive for landslide occurrence. Interaction between geology and long-term climate condition resulted in significantly different landform 


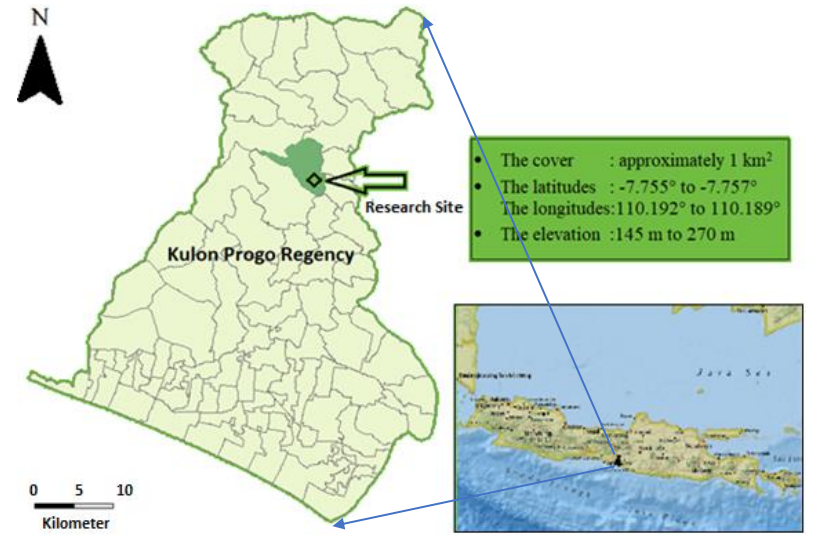

Figure 1: The location of the research area.

with variation of susceptibility degrees of sliding known as the landslide triggering factors.

Due to intensive landslide movement in Pendoworejo Village, Kulon Progo District, it was necessary to carry out related studies on disaster risk-reduction. A deep observation on the geological conditions in the area was required in order to avoid or minimize the risk of ground movement. The results of this research would provide an overview of potential and mechanisms of ground movement, as well as the required recommendations.

The primary aim of this research was to assess the landside hazard in the study area, to estimate the risk and to design a monitoring and early warning system. Such mitigation effort was necessary to prevent disasters, to increase community preparedness and to ensure the best response when the disaster might happen.

\section{Determination OF LANDSLIDE RisK}

\subsection{Influencing Factors of slope stability}

Generally, there are five main causing factors of landslide: topography, geological conditions, hydrological conditions, tectonic activity, vegetation and human activities (Crozier and Glade, 2004). The slope inclination as one of the geomorphological components of an area gives a considerable role in the occurrence of mass movements. The potential of mass movements will increase along with the increase in slope due to the greater driving force on steep slope conditions. The slope as a mass movement controlling factor can be divided into 3 classifications (Karnawati,2005), which include $10-20^{\circ}$ as a flow or a creep, $20-40^{\circ}$ as a spear or a slide, and higher than $40^{\circ}$ as a fall or topple.

Geological conditions consist of the movement of soil/rock generally occurs on slopes composed of weathered rocks and residual soil with a wide and thick distribution, and contains clay minerals. The weathering process mainly plays a role in changing the shape and size of rocks, while alteration processes will change the composition of rocks to be clay like montmorillonite minerals (Braja, 1998). Hydrological condition is one of the main causing factors of the mass-movement. In many cases, a landslide occurs during an extreme storm event. The amount of rain that efficiently triggers slopes failure is $\geq 70 \mathrm{~mm} /$ day in soil that readily absorbs water. The water that infiltrated into the ground will fill the soil pore space and cause the soil to become saturated, resulting in weak soil aggregation and decreased soil shear strength (Mulyono, 2018).

On the other hand, as non-structural slope reinforcement, vegetation can be used as an effort to increase the stability or strength of the slope by using plants or a combination of plants and barrier construction (Noroozi, 2015). Such nonstructural slope strengthening by using plants will bind and hold the soil/rock making up slopes, and control the water infiltration. Rooting roots and tree trunks can act as pegs to hold down the slopes. Tree branches play the role of breaking down rainwater, stopping the rate or energy of the falling rainwater, reducing the amount of run-off, thereby reducing the level of surface erosion. According to Ali et al. (2012), there is more than $8 \%$ difference of safety factor (SF) when tree is located at toe of the slope in compare to situation without effects of trees.

\subsection{Landslide risk elements}

In simple generic terms, the risk index in this research was based on two components: the hazard and vulnerability. The level of risk thus resulted from the intersection of hazard and the value of the elements at risk by way of their vulnerability (Figure 2). Risk assessment is carried out by using technical (geomorphology, geology, and geotechnics), institutional, and socialeconomy-cultural surveys of vulnerable communities (Fathani, 2017). 


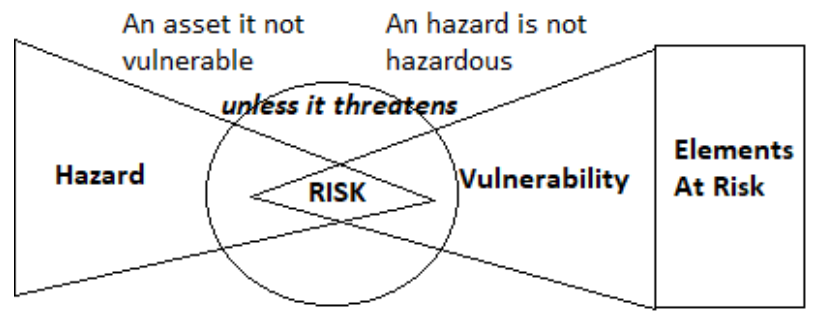

Figure 2: Conceptual relationship between hazard, risk and vulnerability (Glade, 2005).

\subsection{Landslide monitoring and early warning system}

According to Fathani et al. (2014), landslide monitoring and early warning systems should be based on the most appropriate and adaptive technology, with the involvement of the local authority and community participation. Therefore, both technical and communication skills are the main requirements to achieve success in an early warning system program. The system should include some technical aspects such as geological surveys and site selection, design of monitoring equipment which is simple (lowcost) but effective, determination of early warning levels (warning criteria), installation, operation and on-site maintenance.

Social aspects should include social mapping and evaluation, public consultation and dissemination of a program, and community empowerment, including the technical training and evacuation drills for landslide hazard preparedness (Karnawati et al., 2011). The proposed model of landslide early warning has been quite effective and strategic in improving community resilience at landslide-vulnerable villages. It is also crucial that the system should be developed through community participation and the provision of simple and low-cost technology up to real-time technology for early warning.

\section{Research Methodology}

Two main steps in this research consisted of data collection and data analysis. The data collection included primary data and secondary data. The primary data was collected through preliminary and detail investigation. The preliminary survey was carried out to claim the surface deformation and cracks position in the

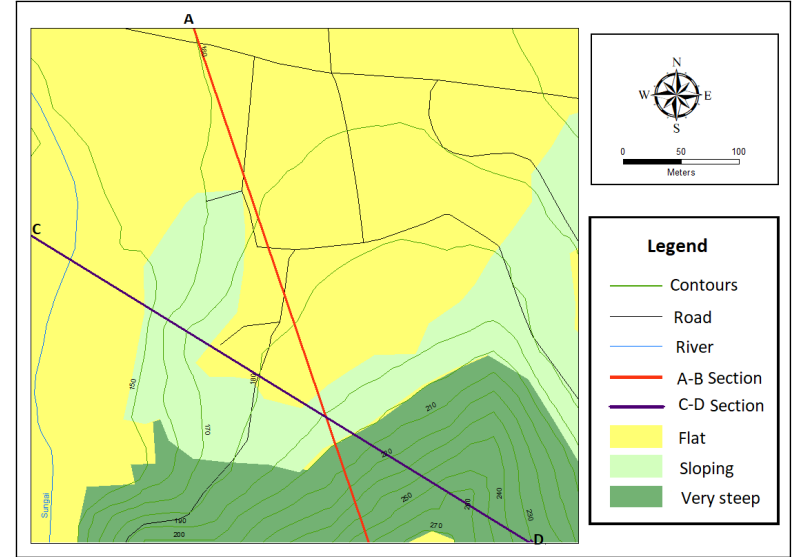

Figure 3: The geomorphology at Pendoworejo.

research area, before the detail investigations were planned and carried out.

There are five commonly methods used in landslide investigation field i.e. field investigation of surface deformation, investigation of geologic structure, evaluation of sliding surface, groundwater investigation, and geotechnical investigation (Japan Landslide Society, 1996). Field survey started with soil sampling taken from the toe of landslide crown and near the cracks of landslide. Then, the laboratory tests were carried out to determine the soil properties. The local people measured the groundwater level fluctuation within certain period. The rainfall data was collected from Indonesian Meteorological, Climatological and Geophysical Agency (BMKG) of the closest rainfall station about $2 \mathrm{~km}$ from the study area. Furthermore, the detailed household data, housing maps and regional traffic were collected for analyzing the risk and designing the monitoring and early warning system.

\section{Results AND Discussion}

\subsection{Geomorphology of the study area}

In general, the morphology developed in Ngrancah hill, Pendoworejo Village is a steep slope $\left(>40^{\circ}\right)$ located on the east side of the Menoreh Mountains. Ngrancah hill is on the slopes of Prahu Mountain which is an isolated hill from the Menoreh Mountains. Figure 3 shows the geomorphological in the study area.

In addition, based on the geomorphological map, the study area could be divided into three geomorphological units with different slope levels, namely steep hill units $\left(>40^{\circ}\right)$, gentle 


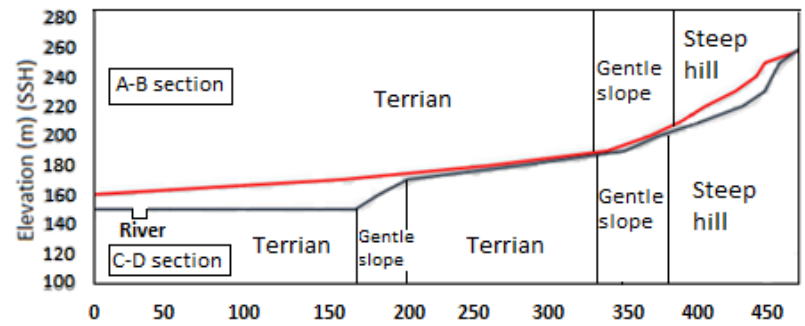

Figure 4: Geometry of cross-section A-B and CD on the Ngrancah Hill.

slope units $\left(10-20^{\circ}\right)$ and terrain units $\left(0-10^{\circ}\right)$. Vertical cross sections of these three geomorphological units can be seen in the Figure 4 .

\subsection{Lithology}

Based on the Regional Geological Map of the Pendoworejo Village (Bemmelen, 1970), the study area is located in the Nanggulan Formation and Old Andesite Formation (Figure 5). The Nanggulan Formation is the oldest lithological unit in this area that composes of ligniteembedded sandstones, sandy marbles, claystone with limonite concretion, nap inserts and limestones, sandstones and tuffs. Meanwhile, the Old Andesite Formation is generally composed of andesite, tuff, agglomerate breccias and insertion of andesite lava flows. Following with on field observations by the Department of Geological Engineering, Faculty of Engineering, Gadjah Mada University (2017), it was found that the lithology in this area was andesite breccia with dark gray and massive structure and in the matrix form of fine-sized volcanic material, in addition to fragments in the form of porphyry andesite of up to bong shape with angular fragments and abundant plagioclase composition. Such composition is commonly found around hilly areas, especially in hills with steep slope.

Most of rocks in the study area have undergone intensive weathering to form a thick layer of soil. In addition, in some bed rocks, it was also found to had undergone changes in composition to clay minerals. The condition of weathered rock and such formation of a thick layer of soil can be one of the triggering factors of soil movement. The mass of soil or rocks that have undergone weathering will be easily infiltrated by water. This will cause increasing mass

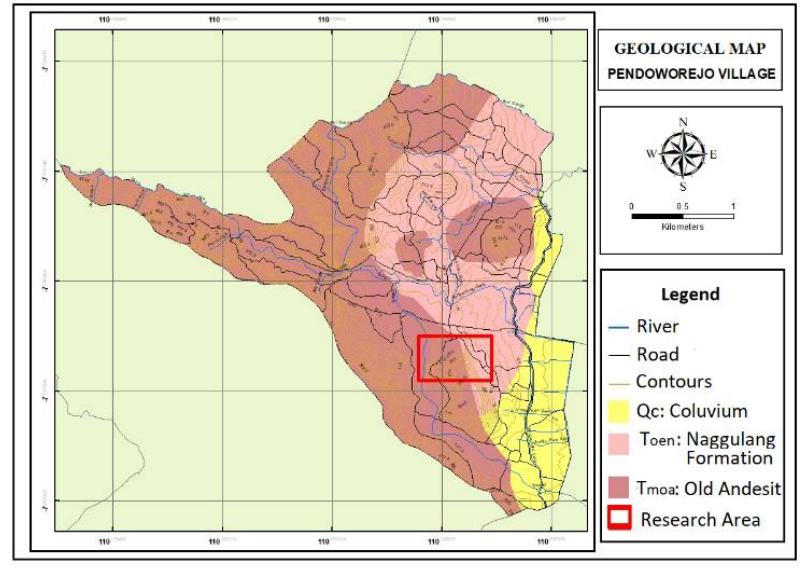

Figure 5: The geological map in Pendoworejo Village.

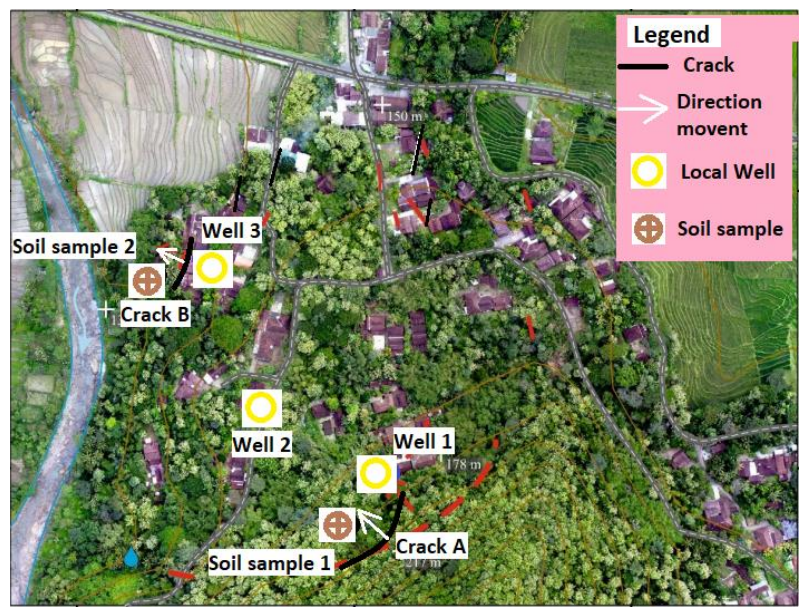

Figure 6: Cracks in the research area and the location of soil sampling.

of the slope constituent material which can also increase similar to land movement.

\subsection{Field investigation}

The general objective of field investigation is to identify all of the significant features of the geologic environment that may impact on the proposed construction (Hunt, 2005). As the result, there was no evidence of mass movement on the west and south part of the hill. Also, there were no local people living on the east part of the site. On the other hand, the north part area was estimated to have risk due to two sites of crack appeared (Figure 6). The Main Crack A appeared in the forest above the Crack B.

Following the observation results since $16^{\text {th }}$ March 2018, the extension of this crack was $17 \mathrm{~mm}$ on $28^{\text {th }}$ November $2018,18 \mathrm{~mm}$ on $05^{\text {th }}$ January 2019, $20 \mathrm{~mm}$ on $23^{\text {th }}$ February and 
$28 \mathrm{~mm}$ on $31^{\text {th }}$ March 2019. These data were essential to validate the correction of the velocity calculated by using the visco-plastic model (Corominas et al., 2005; Faris and Fathani, 2013).

Figure 7 indicates the rainfall and groundwater levels at Pendoworejo Village during 4 months continuously, from $1^{\text {st }}$ December 2018 to $31^{\text {th }}$ March 2019 . The daily rainfall data was collected from BMKG, which was taken from the rainfall station of about $2 \mathrm{~km}$ from the study area. The groundwater level was measured from the local well on December 2018 and March 2019 and then simulated under the tank model for the consecutive months.

Tank model which was used for estimating groundwater level considered the geological formation that occurred in particular area (Hong et al., 2005; Faris, 2010; Naing, 2018). The tank model applied in this research was based on the tank used in Zentoku landslide. However, by considering the difference of geological structures and the landslide scale, the tank was designed. As the results, the volume error $\left(V_{e}\right)$ and coefficient of correlation $(R)$ of the simulation result obtained permitted value of $\left(V_{e}<\right.$ $5 \%$ and $R \approx 1$ ). It could be concluded that the assumption of geological formation used in the tank model simulation was appropriate. Accordingly, the result from the tank model were used to simulate groundwater level in order to set the water pressure input in visco-plastic model to calculate the velocity of the landslide movement.

\subsection{Landslide hazard and risk}

As mentioned in the section 2, the concept of risk has two components: hazard and vulnerability. The landslide hazard in term of safety factor and the vulnerability can be determined by the amount of damages possibly caused by the hazard. In this case, the vulnerability was the number of residential houses at the risk area. Furthermore, the vegetation was the natural mitigation effort to decreases the vulnerability of the area.

In this research, the risk area could be divided into three areas: high risk, medium risk and low risk. The high risk area was the region near Crack $A$ and the medium risk area was located around Crack B. On the other hand, being located in the terrain, the north part of the vil- lage was assessed as the low risk area despite of many appearing of small cracks in this area.

Figure 8 describes the landslide displacement in Pendoworejo Village from 2nd December 2018 to the end of March 2019. Overall, the displacement rose slightly in the beginning. In Crack A, the landslide velocity was slow on December 2019 and faster in the following months. In the meantime, the value in Crack B was approximately zero until mid-February 2019. Then, it grew significantly before when the groundwater depth began to become lower than $5 \mathrm{~m}$. Moreover, the displacement at Crack A was more than 10 times larger than at Crack $B$. The average velocity at Crack $A$ and Crack B were $1.1 \times 10^{-5} \mathrm{~mm} / \mathrm{s}$ and $1.1 \times 10^{-6} \mathrm{~mm} / \mathrm{s}$, respectively. Based on the landslide velocity scale (Cruden and Varnes, 1996), the mass movement types in the research areas was creep.

\subsection{The landslide monitoring and early warning system}

In this research, Gadjah Mada-Early Warning System (GAMA-EWS) is recommended to be applied in Pendoworejo Village because not only simple to install and use, it is also a low cost-effective system (Fathani, 2008). Developed by Universitas Gadjah Mada, since 2007, GAMA-EWS have been installed on more than 100 districts in 28 provinces in Indonesia and Myanmar.

Figure 9 shows the setting-up of a monitoring and early warning system that was recommended for Pendoworejo Village. Under this system, the tiltmeter was not installed because the slope was small and the landslide hazard was insignificant. In addition, the installation the tiltmeter was quite costly. Thus, the tiltmeter in this case was unnecessary. On the other hand, using the extensometer to monitor the landslide movement was sufficient. The receiver and online system was located at house of head of village. The rain gauge was located on area with no high buildings, trees or other obstacles that could obstruct rain from entering the collector (Faris, 2010). Moreover, because the village was in the crowed of plan, the system required two sound sirens to ensure the warning is well informed to all families in the area. 


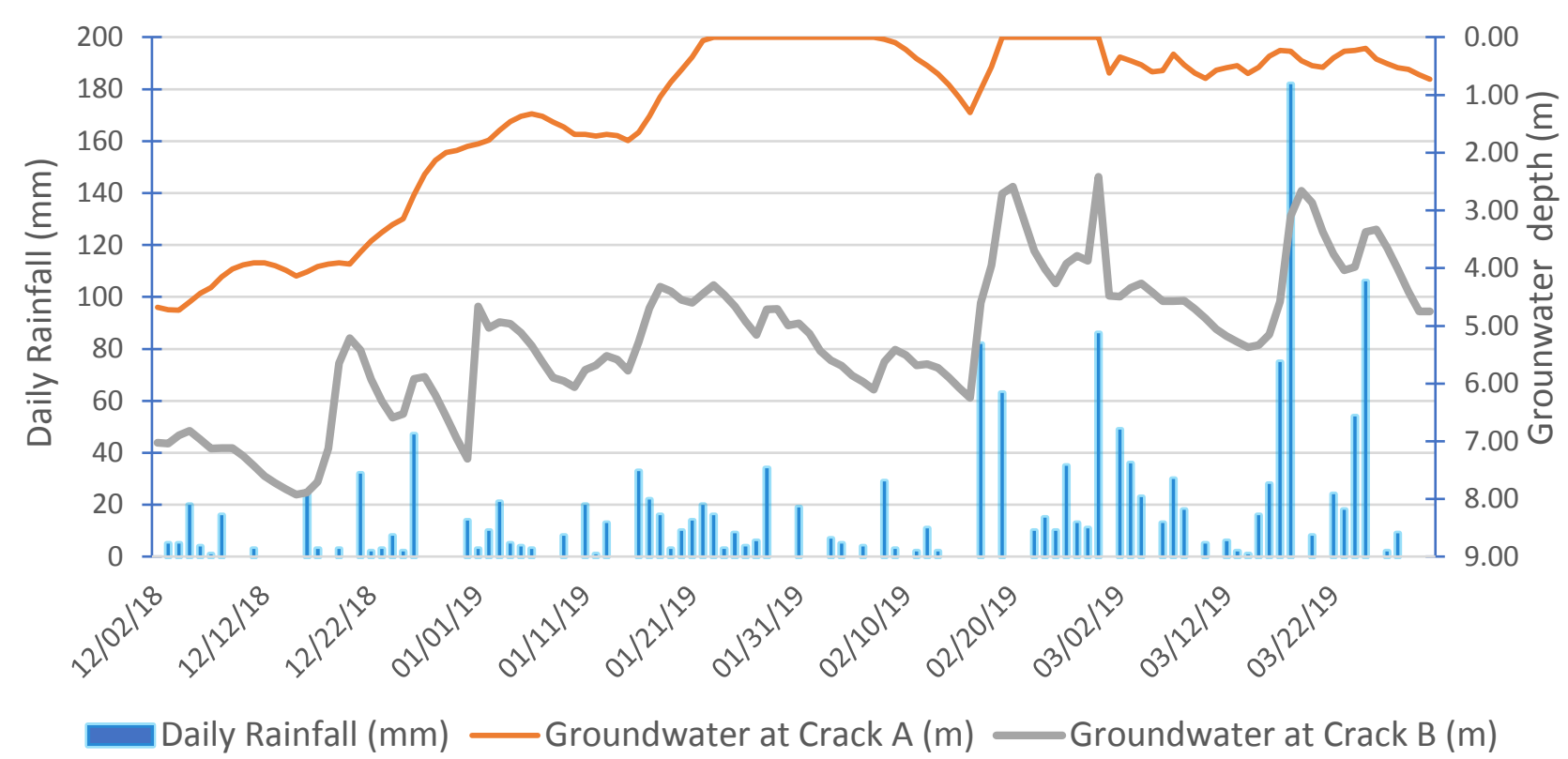

Figure 7: The daily rainfall and simulated groundwater in Pendoworejo from Dec 2018-Mar 2019.

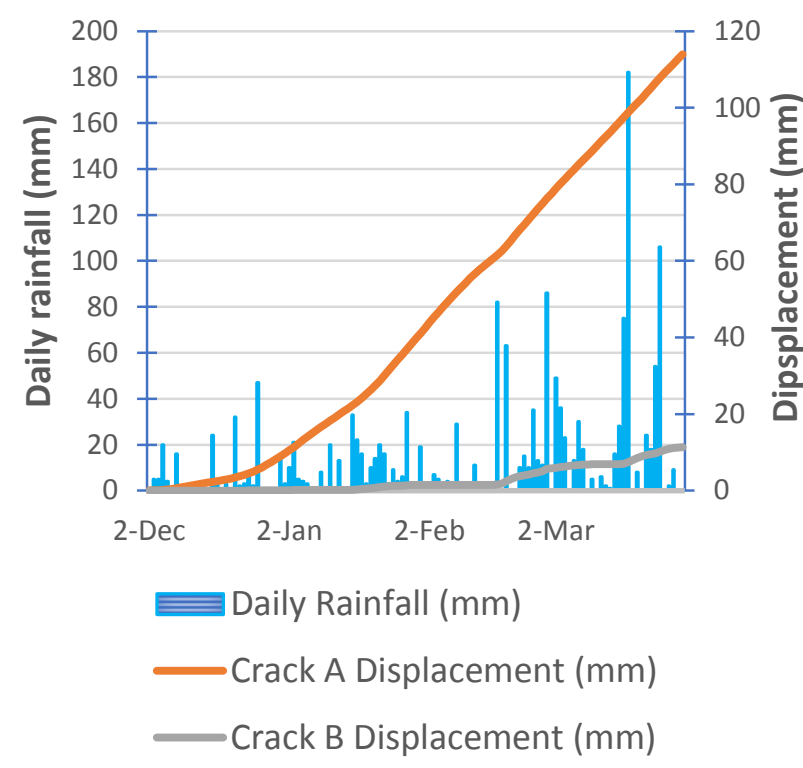

Figure 8: The displacement based on the rainfall intensity at two cracks in the research area.

\section{CONCLUSION AND RECOMMENDATION}

The rainfall and the fluctuation of the groundwater levels substantially affected the slope stability in the village of the research area. In fact, the fluctuation of the groundwater level rose and dropped substantially before and after heavy rainfall.

Although the landslide hazard increased significantly in the wet season, the movement of landslide also increased significantly after midrainy season. The assessed risks in the Pen- doworejo could be divided into three areas: high risk, medium risk and low risk. The high risk area was the region near to Crack A. Similarly, the medium risk area was the region near to Crack B. Moreover, the flat or very sloping areas stood on low risk area.

In the future, such risk could be more hazardous, specifically during the rainfall season. Thus, installing the monitoring and early warning system is an appropriate mitigation effort for this area. Furthermore, the GAMA-EWS was recommended. Then, training the local people about the landslide hazard and evacuation simulation was crucial in order to decrease the vulnerability in the area. To conclude, crowed plants in the village are the best mitigation effort to cope with the landslide hazard. The root of the tree is proven to be the natural archon. Therefore, to protect the area, flora is necessary

\section{REFERENCES}

Ali, N., Farshchi, I., Mu'azu, M. A. and Rees, S. W. (2012) Soil-Root Interaction and Effects on Slope Stability Analysis. Electric Journal of Geotecnical Engineering. Vol. 17, Bund. C. pp:319-328.

Braja, M. Das., (1998) Principles of Geotechnical Engineering. PWS Publishing Company, Boston.

Corominas, J., Moya, J., Ledesma, A., Lloret, A. \& Gili, J. A. (2005) Prediction of ground displacement and velocity from groundwater level 


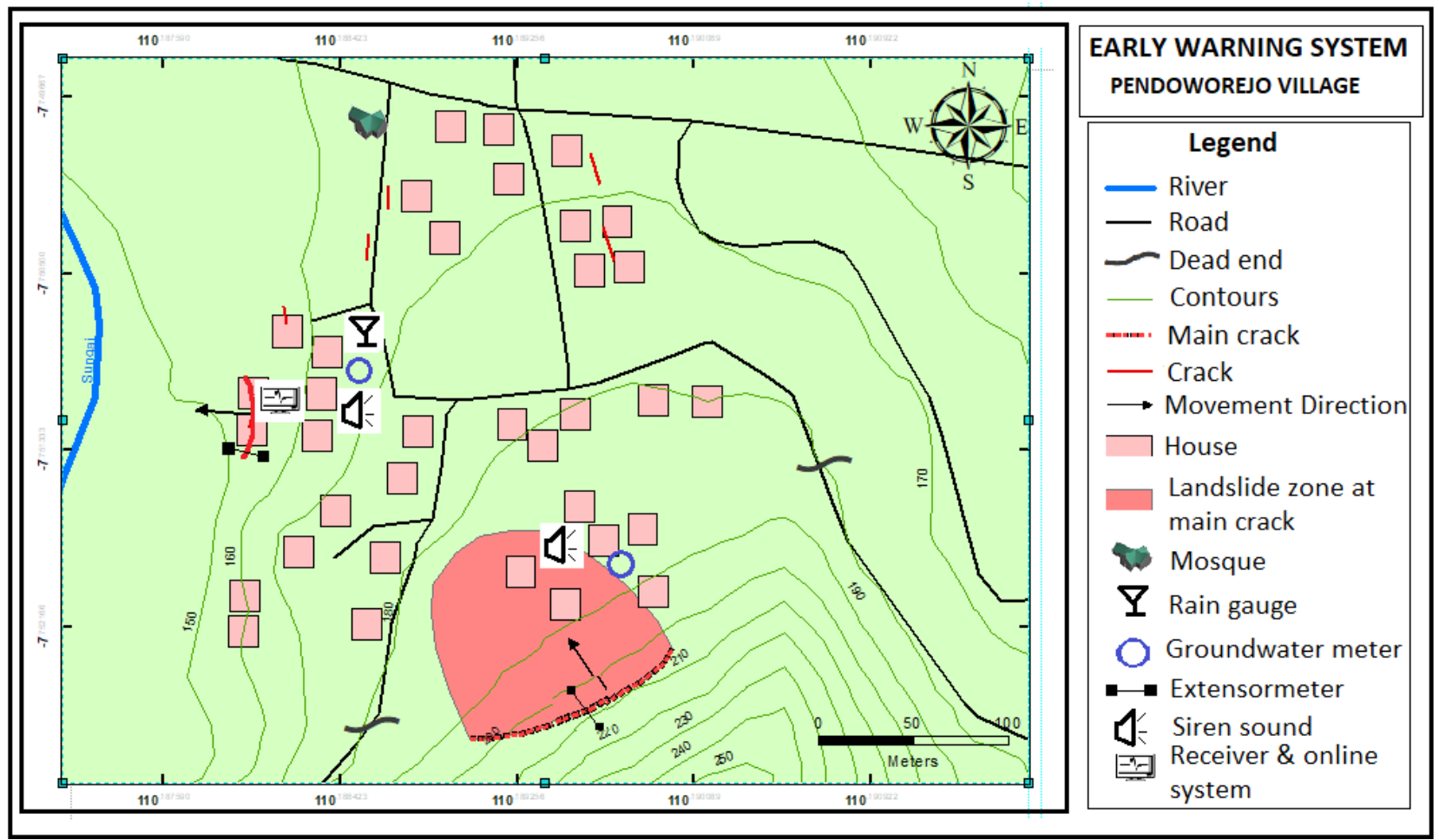

Figure 9: The design of monitoring and early warning system in Pendoworejo Village.

changes at the Vallecbre Landslide (Eastern Pyerness, Spain). 83-96. doi: 10.1007/s10346-0050049-1.

Cruden, D. M. \& Varnes, D. J. (1996) Landslide type and processes. Landslide: Investigation and mitigation, 247, 36-75.

Department of Geological Engineering, Faculty of Engineering, Gadjah Mada University (2018) Kajian Geologi Gerakan Tanah Di Desa Pendoworejo, Kecamatan Girimulyo, Kabupaten Kulon Progo.

Fathani, T.F., Karnawati, D., Sassa, K., Fukuoka, H. and Honda, K. (2008) Development of Landslide Monitoring and Early Warning System in Indonesia.

Fathani, T.F., Karnawati, D., and Wilopo. W. (2014) An Adaptive and Sustained Landslide Monitoring and Early Warning System. K. Sassa et al. (eds), Landslides Science for a Safer Geoenvironment, Vol 2, doi: 10.1007/978-3-31905050-8_87, Springer, Switzerland.

Fathani, T.F., Karnawati, D., and Wilopo. W. (2017) Promoting a Global Standard for CommunityBased Landslide Early Warning System (WCoE 2014-2017,IPL-158,IpL-165). K. Sassa et al. (eds), Advancing Culture of Living with Landslide, doi: 10.1007/978-3-319-59469-9_30.

Faris, F. (2010) Dynamic simulation of rainfall triggering landslide movement by visco-plastic model. Graduate Thesis. Civil and Environ- mental Engineering Department, Gadjah Mada University, Yogyakarta.

Faris, F. \& Fathani, T. F. (2013) A coupled hydrology/slope kinematics model for developing early warning criteria in the Kalitlaga Landslide, Banjarnegara, Indonesia. Progress of GeoDisaster Mitigation Technology in Asia", doi: 10.1007/978-3-642-29107-4_26, 453-467.

Hong, Y., Hiura, H., Shino, K., Sassa, K. \& Fukuoka, H. (2005) Quantitative assessment on the influence of heavy rainfall on the crystalline schist landslide by mornitoring system-case study on Zentoku landslide, Japan. Landslide, (December 2004), 31-41. doi: 10.1007/s10346-005-0044-6.

Hunt, R.E. (2017) Geotechnical investigation methods - A field guide for Geotechnical Engineers. Taylor and Francis Group, Boca Raton.

Karnawati, D. (1998) Natural slope failure on weathered andesitic brecia in Samigaluh area, Indonesia. Fourth International Conference on Case Histories in Geotechnical Engineering, St. Louis, Missouri.

Karnawati, D. (2005) Bencana Alam Gerakan Massa Tanah di Indonesia dan Upaya Penanggulangannya. Jurusan Teknik Geologi, Fakultas Teknik, Universitas Gadjah Mada, Yogyakarta.

Karnawati, D., Fathani, T.F., Andayani, B., Legono, D., Burton, P.W. (2011) Landslide hazard and community-based risk reduction effort in Karanganyar and the surrounding area Central Java, Indonesia. J Mt Sci 8(2): 149-153. 
Glade, T., Anderson, M. and Crozier, M.J. (2005) Landslide Hazard and Risk. John Wiley and Sons Ltd, The Atrium, Southern Gate, Chicester.

Mulyono, A., Subardja, A., Ekarasi, I., Sudirja, R. and Ningrum, W. (2017) The Hydromechanics of Vegetation for Slope Stability. Global Colloquium on GeoScience and Engineering 2017. Series: Earth and Environmental Science 118 (2018) 012038, doi: 10.1088/1755-1315/118/1/012038.

Naing, M. T., Fathani, T. F. and Wilopo, W. (2018) Estimating the Velocity of Landslide Movement Us- ing Visco-Plastic Model in Jeruk Sub-village, Kulon Progo District, Yogyakarta, Indonesia. Journal of the Civil Engineering Forum. Vol.4 No.3.

Nakamura (1996) "Landslide in Japan". The Japan Landslide Society National Conference of Landslide control.

Noroozi, A. G. and Hajiannia, A. (2015) The effect of vegetation on slope instability as predicted by the finite element method.

Van Bemmelen, R.W. (1970) The Geology of Indonesia. Volume 1A. Haque, Netherlands. 